\title{
Effects of Dietary Acids on Surface Microhardness of Various Tooth-colored Restoratives
}

\author{
Yavuz GÖMEÇ, Can DORTER, Handan ERSEV1, Begüm GURAY EFES and Esra YILDIZ \\ Department of Operative Dentistry, \\ ${ }^{1}$ Department of Endodontics, \\ Faculty of Dentistry, Istanbul University, Capa 34390, Istanbul, Turkey \\ Corresponding author, E-mail:yavuzgom@yahoo.com
}

Received January 23, 2004/Accepted April 27, 2004

\begin{abstract}
The aim of this in vitro study was to investigate if surface microhardness of Fuji IX GP, Vitremer, Dyract AP, and Prodigy is influenced by conditioning in aqueous solutions of lactic, orthophosphoric, citric, and acetic acids against bidistilled water (which was used as control). The $\mathrm{pH}$ values of acids used in this study were representative of dietary acids. All specimens were stored in bidistilled water for one week and then conditioned in the respective test solutions for another week. Citric $(p<0.05)$ and acetic acids reduced, while lactic and orthophosphoric acids $(p<0.05)$ increased the microhardness of both Fuji IX GP and Vitremer. On the other hand, microhardness of both Dyract AP and Prodigy was significantly reduced by all acidic media $(p<0.05)$. The observed differences in the surface microhardness of various tooth-colored restorative materials conditioned in several media varied not only with the $\mathrm{pH}$ but also the nature of the acidic solution, and with the composition of the evaluated material.
\end{abstract}

Key words: Tooth-colored restoratives, Surface microhardness, Dietary acids

\section{INTRODUCTION}

Tooth-colored restorative materials play an important role in clinical dentistry, and recent advances have led to a substantial increase in their use. However, extensively damaged layers have been detected on non-stress bearing and occlusal surfaces in clinically-worn composite restorations ${ }^{1)}$, and it was assumed that the chemical environment has appreciably influenced the degradation of these materials in vivo ${ }^{2-4)}$. A material's surface resistance to chemical degradation and its mechanical properties are related to its wear resistance ${ }^{5,6)}$, and hardness measurements allow relative determination of this behavior ${ }^{7}$.

To be clinically successful, tooth-colored restorative materials are required to have long-term durability $^{8)}$ and a high degree of long-term wear resistance in the oral cavity ${ }^{9,10)}$. But the oral cavity is a complex, aqueous environment where the restorative material is in contact with saliva ${ }^{8)}$. In addition', other factors (such as low $\mathrm{pH}$ due to acidic foods) may also influence a material's physical and mechanical characteristics ${ }^{11)}$. It has been shown that $\mathrm{pH}$ varies in the oral environment and on tooth surfaces ${ }^{12)}$, and $\mathrm{pH}$ fluctuations - besides the action of hydrolytic enzymes in saliva - may exacerbate surface hardness reduction $^{13,14)}$. In a clinical environment, a material's hardness loss may contribute to the deterioration of the material ${ }^{10)}$. However, though the $\mathrm{pH}$ value of an acidic food plays an important role in surface hardness reduction, it is not the only important factor ${ }^{15)}$. The interaction of acids is another contributing factor, and it involves not only acid characters but varies with the structural features of acid molecules too $^{16,17)}$. Unfortunately, limited information is available on how various clinically relevant acid solutions alter the surface microhardness of tooth-colored restorative materials ${ }^{3,11,15)}$. Therefore, a good knowledge of how hardness is affected by dietary acids consumption will definitely help to shed light on its clinical behavior in the oral cavity. Against this background, the aim of this in vitro study was to investigate if Vickers hardness of various tooth-colored restorative materials is influenced by conditioning in aqueous solutions of lactic, orthophosphoric, citric, and acetic acids at $\mathrm{pH}$ values representative of dietary acids in comparison to conditioning in bidistilled water.

\section{MATERIALS AND METHODS}

Four different types of tooth-colored restorative materials were used in this study. They are namely: a conventional glass-ionomer cement (Fuji IX GP, GC Int. Corp., Tokyo, Japan), a resin-modified glassionomer (Vitremer, 3M Dental Products Division, St. Paul, MN, USA), a polyacid-modified composite resin (compomer) (Dyract AP, Dentsply De Trey GmbH, Konstanz, Germany), and a hybrid composite resin (Prodigy, Kerr Co., Orange, CA, USA) (see Table 1).

Thirty-five samples of each material were handled according to manufacturers' instructions and inserted into polypropylene molds with internal dimensions of $10 \mathrm{~mm}$ diameter by $2 \mathrm{~mm}$ thickness. 
Table 1 Technical profiles of tooth-colored restorative materials evaluated (based on information by manufacturers)

\begin{tabular}{cccc}
\hline Material & Type & Matrix & Filler \\
\hline Fuji IX GP & Glass-ionomer cement & $\begin{array}{c}\text { Polyacrylic acid, } \\
\text { polybasic carboxylic acid }\end{array}$ & F-Al-silicate glass \\
Vitremer & Resin-modified glass-ionomer cement & Organic salts, HEMA resin & F-Al-silicate glass \\
Dyract AP & Polyacid-modified resin composite & UDMA, TCB resin & Sr-Al-F-silicate glass \\
Prodigy & Hybrid composite & Ethoxylated Bis-GMA/ & Ba-Al-boro-silicate glass, \\
& & TEGDMA & colloidal silica \\
\hline
\end{tabular}

The surface of each sample was covered by a Mylar matrix strip and a glass slab. The glass-ionomer cement was allowed to set for 1 hour, while other restorative materials were polymerized by light irradiation for 40 seconds (Optilux 401, Demetron, Danbury, CT, USA). All samples were then stored for 24 hours in bidistilled water at $37^{\circ} \mathrm{C}$. Following which, the samples' surfaces were polished with medium, fine and superfine aluminum oxide abrasive disks (Hawe/Neos Dental, Bioggio, Switzerland). After each polishing step, specimens were flushed with air-water spray. Finally, all specimens were stored in bidistilled water at $37^{\circ} \mathrm{C}$ for one week.

For conditioning in four different dietary acids, the following preparations were made:

- To simulate ayran (mixture of yoghurt and water), an aqueous solutions of $7 \times 10^{-4} \mathrm{M}$ lactic acid (Merck, Darmsadt, Germany) was prepared, which gave a $\mathrm{pH}$ measurement of 3.61 .

- To simulate cola (Coca-Cola, İstanbul, Turkey), an aqueous solutions of $2 \times 10^{-2} \mathrm{M}$ orthophosphoric acid (Fluka, Neu Ulm, Germany) was prepared, which gave a $\mathrm{pH}$ measurement of 1.95 .

- To simulate $100 \%$ lemon juice, an aqueous solutions of $1 \times 10^{-3} \mathrm{M}$ citric acid (Fluka, Neu Ulm, Germany) was prepared, which gave a $\mathrm{pH}$ measurement of 3.23 .

- To simulate vinegar (Vefa, İstanbul, Turkey), an aqueous solutions of $0.7 \mathrm{M}$ acetic acid (Merck, Darmsadt, Germany) was prepared, which gave a $\mathrm{pH}$ measurement of 2.45 .

Each of the four restorative material groups was then subdivided into five subgroups with seven specimens each. The specimens in each subgroup were conditioned in their respective acidic solution or bidistilled water, used as control, at $37^{\circ} \mathrm{C}$ for one week.

Surface microhardness measurements were carried out using a hardness tester (Zwick 3212, Ulm, Germany). Each specimen was subjected to three indentations under a 500-gram load for 30 seconds at randomly selected areas. The average of these three measurements was then calculated. Finally, the data were statistically analyzed by one-way ANOVA and
Tukey's multiple comparison tests.

\section{RESULTS}

The mean surface microhardness values (VHN) and standard deviations of Fuji IX GP, Vitremer, Dyract $\mathrm{AP}$, and Prodigy following conditioning in the test solutions are given in Fig. 1. When compared against samples conditioned in bidistilled water, the following results were obtained:

- Surface microhardness of both Fuji IX GP and Vitremer was reduced after conditioning in acetic acid and citric acid solutions, but significant reduction was observed only for citric acid solution $(\mathrm{p}<0.05$ and $\mathrm{p}<0.01$ respectively)

- After lactic acid and orthophosphoric acid conditioning, Fuji IX GP and Vitremer revealed significantly higher microhardness values $(p<0.05)$.

- As for Dyract AP and Prodigy, their surface hardness was significantly reduced by all acidic media $(\mathrm{p}<0.05)$.

- Although there were no statistically significant differences among them, the solutions are ranked as follows for Dyract AP and Prodigy:

Dyract AP: lactic acid>orthophosphoric acid $>$ citric acid $>$ acetic acid

Prodigy: lactic acid $>$ orthophosphoric acid $>$ acetic acid $>$ citric acid

\section{DISCUSSION}

Glass-ionomers include the subset of materials known as resin-modified glass-ionomers ${ }^{18)}$. In resin-modified glass-ionomers, traditional neutralization is complemented by polymerization due to the presence of side groups that can be cured through free radical mechanisms ${ }^{19,20)}$. Forss ${ }^{21)}$ reported that light-curing glassionomer cements - like conventional cements - are usually susceptible to chemical erosion. Therefore, the glass-ionomer cement, Fuji IX GP, and the resinmodified glass ionomer cement, Vitremer, expectedly revealed similar results in the present study.

When compared against bidistilled water control, acetic acid and citric acid solutions reduced the microhardness of both Fuji IX GP and Vitremer, but 


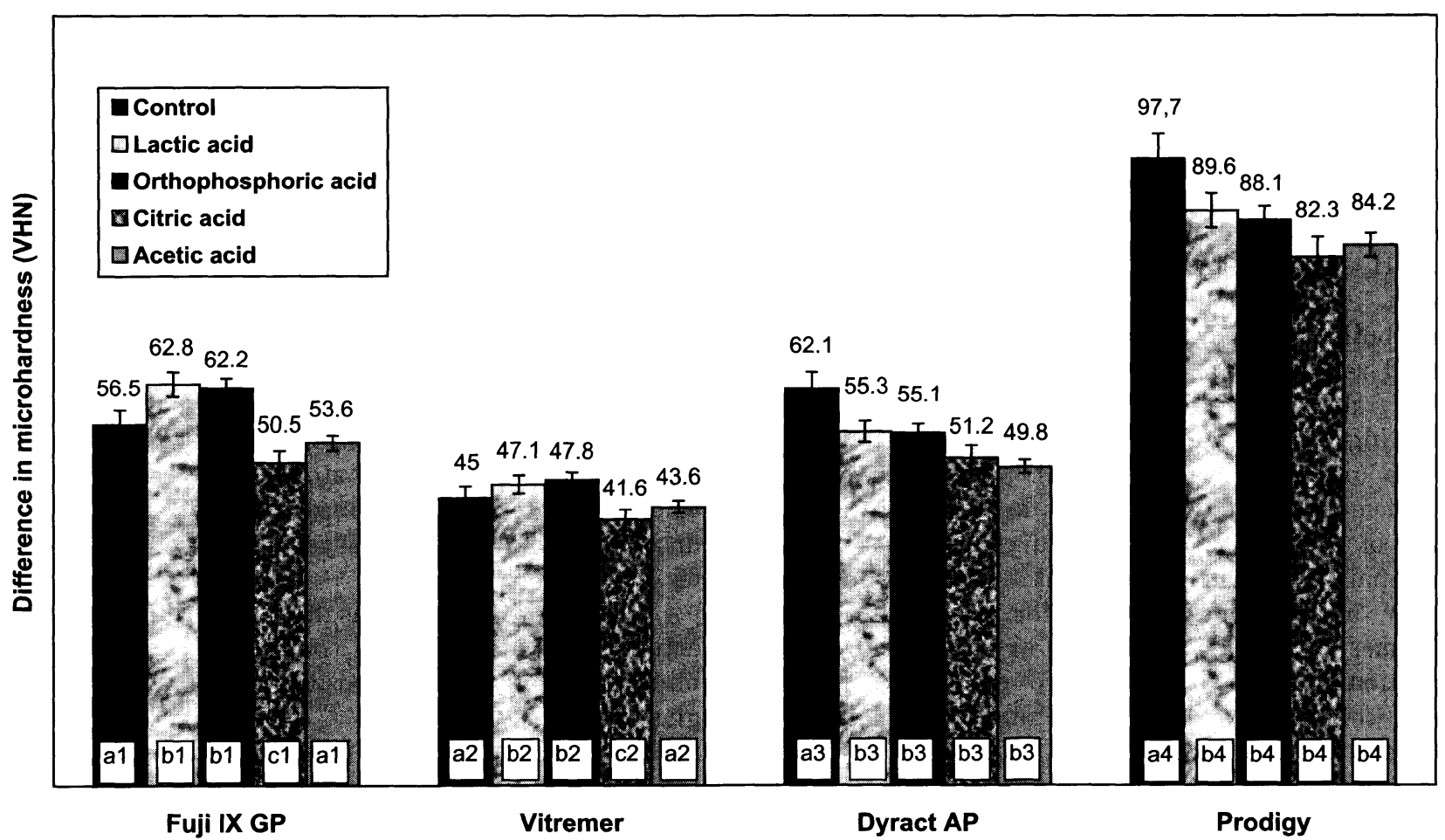

Fig. 1 The mean average microhardness values (VHN) of materials. Columns with same letters are not significantly different at $\mathrm{p}>0.05$ level.

significant reduction was observed only for citric acid solution. In accordance with our findings, Abu-bakr et $a l .{ }^{15)}$ - who evaluated the effect of low-pH soft drinks on the surface microhardness, solubility, and surface texture of tooth-colored restorative materials - found that a resin-modified glass-ionomer cement immersed in orange juice ( $\mathrm{pH} 3.83)$ exhibited significantly lower hardness values than when immersed in deionized water for seven days. Likewise, Nicholson et $a l .{ }^{17)}$ - who studied the behavior of tooth-colored restorative materials in various clinically relevant acid solutions - reported that the glass-ionomer showed the greatest mass loss in citric acid. The authors immersed their specimens in phosphoric acid ( $\mathrm{pH} 2.1$, for model response to Coca-Cola ${ }^{\mathrm{TM}}$ ), lactic acid ( $\mathrm{pH}$ 2.7, for model response to active caries),

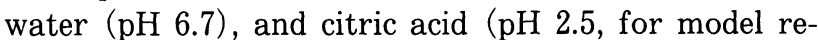
sponse to fruit juices). They then concluded that citric acid is the most aggressive storage medium for glass-ionomer cement. They also reported that interaction of acids was a key factor that led to this result.

Acids interaction depends not only on acid characters, but that it varies with the structural features of acid molecules too ${ }^{17)}$. $\mathrm{H}^{+}$ions' concentration and the formation constants for soluble complexes between acid anions and metal cations in the set cement control the degree of glass-ionomer cement's erosion in organic acid solutions ${ }^{22}$. The dissolution of glass-ionomer cements in acetic acid ${ }^{23,24)}$ solution was found to be controlled by diffusion of the eluted species in the cement matrix, which depended on $\mathrm{H}^{+}$ ions' concentration. The long immersion thus resulted in complete dissolution of the glass particles. In citric acid solutions, however, the dissolution was shown to depend upon both the diffusion and the chelating reaction between the acid anions and the eluted species at the cement surface. The surface reaction then resulted in rapid dissolution of the cement matrix ${ }^{24)}$. Citric acid has a large complexing ability with metal cations. As a result, the amount of elution into citric acid solution was much larger than that into acetic acid solution ${ }^{24)}$. DeMoor and Verbeeck ${ }^{25)}$ showed that when compared to elution in water, an increased amount of fluoride was released from glass-ionomer cements into acetic acid solution. This is caused by an additional leaching of glass particles in the surface layer of the cement. Their findings were substantiated by the investigation results of Fukuzawa et $a l^{23)}$. They found no evidences of any polysalt matrix breakdown, but only a nearly complete degradation of glass particles in a region about $30 \mu \mathrm{m}$ from the surface after 90 days' immersion of the glass-ionomer cement in an acetic acid solution. In the present study, the minus effect on surface hardness may result from higher filler leaching $^{8)}$ from glass-ionomer and resin-modified glassionomer cements in acetic acid solution. 
Fuji IX GP and Vitremer revealed significantly higher microhardness values after lactic acid and orthophosphoric acid conditioning when compared with the ones following bidistilled water conditioning. Nicholson et al. ${ }^{19)}$ demonstrated that a variety of commercial glass-ionomer cements, including one resin-modified material, were capable of increasing the $\mathrm{pH}$ of lactic acid solutions in which they were stored. Nicholson et al. ${ }^{17)}$, at a later date, showed that both phosphoric and lactic acid solutions appeared relatively benign towards a glass-ionomer cement, and reported that there was a distinct buffering effect, i.e., the materials increased the $\mathrm{pH}$ of the medium towards neutral. Nicholson et $a l^{26)}$ also demonstrated that there is a link between buffering of aqueous lactic acid and erosive loss of conventional glass-ionomer cement. Our findings of higher microhardness values for Fuji IX GP and Vitremer after lactic acid and orthophosphoric acid conditioning - as compared to the ones following water conditioning - may in part be explained by the data provided by Nicholson et al. ${ }^{17,19,26)}$.

Nicholson et $a l .{ }^{19)}$ showed that a variety of commercial glass-ionomer cements, including one resinmodified material, revealed modest mass increases in lactic acid solution in comparison to storage in water. This might indicate that when reaction takes place between the cement and the aqueous lactic acid, a small amount of insoluble glass-lactate is formed. Nicholson et al. ${ }^{17)}$ also found that a glass-ionomer showed a net mass gain in both phosphoric acid and lactic acid. They concluded that this mass gain is likely to be because of an uptake of water that is not exceeded by material loss (due to erosion). Furthermore, the authors stated that the mass gain could be attributed to deposition of insoluble salts on the surface layer, especially in the case of phosphoric acid, the calcium salts of which are known to be substantially insoluble. El-Badrawy et $a$. $^{27)}$ also reported that phosphoric acid is capable of forming stable complexes with metal ions in the ionomer. Okada et $a l^{8)}$ found that saliva has the remarkable effect of increasing surface hardness of Fuji IX GP with time, and reported that $\mathrm{H}_{2} \mathrm{O}$ ligand attached to aluminum and strontium ions in the hydrogel matrix of the cement could easily switch to the phosphorus ions originated from saliva. These connections would lead to the formation of a thin layer on the cement's surface, which may contain calcium phosphate and aluminum phosphate with high ionic bonding and low solubility. The authors reported that the conventional glass-ionomer cement absorbed some inorganic ions and increased the surface hardness. In the present study, Fuji IX GP and Vitremer increased in microhardness following orthophosphoric acid and lactic acid conditioning in comparison to water control. Data obtained from above-mentioned studies thus suggested that absorption of some inorganic ions or deposition of stable complexes might be another explanation for the higher hardness values obtained for Fuji IX GP and Vitremer.

In contrast to our findings, Abu-bakr et $a l .{ }^{15)}$ demonstrated that a resin-modified glass-ionomer cement immersed in Coca-Cola soft drink ( $\mathrm{pH}$ 2.62) exhibited lower hardness values than when immersed in deionized water for seven days. The discrepancy between our findings may be due to different $\mathrm{pH}$ values of the test solutions and conditioning techniques. In the present study, specimens were conditioned in the test solutions for a week without interruption following a week of immersion in bidistilled water. As for Abu-bakr et al. ${ }^{15)}$, they stored their specimens in deionized water and immersed them in Coca-Cola soft drink for only 3 hours everyday over a test period of 60 days.

Previous investigations have described the properties of polyacid-modified composite resins as resembling those of resin composites rather than those of glass-ionomer materials ${ }^{28-30)}$. In agreement with these investigations, the present study showed that the polyacid-modified composite resin (compomer), Dyract AP, revealed similar results to the composite resin, Prodigy. The surface hardness of both Dyract AP and Prodigy was significantly reduced by all acidic media in comparison to the bidistilled water control. Although there were no statistically significant differences among them, the test solutions are ranked as follows for Dyract AP: lactic acid $>$ orthophosphoric acid>citric acid>acetic acid; for Prodigy, the ranking is: lactic acid $>$ orthophosphoric acid $>$ acetic acid $>$ citric acid.

Previous studies have revealed that compomers release higher amounts of fluoride into acidic buffers than into neutral buffers, indicating that the structure of compomers is disintegrated at low $\mathrm{pH}^{11)}$. Under acidic conditions, they are surface-softened ${ }^{31)}$, and demonstrated reduced abrasion resistance ${ }^{32)}$ and higher solubility ${ }^{15)}$. And in general for composite resin materials, lower $\mathrm{pH}$ has been shown to negatively affect wear resistance ${ }^{33,34)}$ and solubility ${ }^{15,35)}$. Consistent with our findings, Nicholson et al. ${ }^{17)}$ detected that citric acid, in comparison to phosphoric acid and lactic acid, was the most aggressive storage medium for compomers. This is because compomers showed the greatest mass loss in this medium. By contrast, the pure composite resin was found to be relatively unaffected by all of the acid solutions examined. However, Örtengren et al. ${ }^{35)}$ observed a significant increase in solubility of composite resin materials - depending on the $\mathrm{pH}$ of the citric acid solution and storage time. One of the materials investigated by Örtengren et $a l^{35}{ }^{35}$ was Spectrum TPH, a BIS-EMA based composite including $\mathrm{Ba}-\mathrm{Al}$ borosilicate glass fillers like Prodigy (which was used in the present study). The difference in data obtained from the present study and by Nicholson et 
$a l .{ }^{17)}$ might be explained by the composition of the tested composite resins.

Again in accordance with our findings, Nicholson et $a{ }^{17)}$ stated that, unlike citric acid, both phosphoric acid and lactic acid solutions appeared relatively benign towards compomers, which are capable of buffering aqueous acid solutions ${ }^{17,19,36)}$. The extent of this buffering capability varied with storage duration and acid nature. In contrast, no equivalent changes were found to occur for the conventional resin composite ${ }^{17)}$. (However, Karantakis et al. ${ }^{20)}$ detected a significant difference in the amounts of fluoride released from Dyract and a fluoride-containing composite resin when immersed in lactic acid and water. They therefore stated that these materials would be expected to be more resistant to dissolution in acidic conditions.) In agreement with our findings, AbuBakr et $a l{ }^{15)}$ reported that surface hardness readings of three compomers - including Dyract - and a composite resin were significantly higher after seven days of immersion in deionized water than in $100 \%$ orange juice and Coca-Cola soft drink. The $\mathrm{pH}$ values of deionized water, $100 \%$ orange juice and CocaCola soft drink were 5.62, 3.83 and 2.62 respectively. When these materials were immersed in orange juice, they showed a remarkable decrease in their mechanical properties, especially that of surface microhardness over a 60-day period. The authors found that immersion in orange juice reduced the microhardness values more than immersion in CocaCola soft drink though the latter's pH was lower than that of $100 \%$ orange juice. Based on these results, the authors stated that apart from low $\mathrm{pH}$, high titratable acidity - which indicates a medium's erosive potential - is also another important factor in altering a material's surface microhardness. The titratable acidity of $100 \%$ orange juice is higher than that of the cola drinks ${ }^{15)}$.

Yap et $a l .^{3)}$ examined the effects of foodsimulating liquids on the surface roughness and hardness of compomers and composites. They reported that the observed differences in hardness for various materials, after conditioning in different food-simulating liquids, could be attributed to the chemical compositions of the materials and the influences of food-simulating liquids on the different chemical components. Following conditioning in water, lactic acid and citric acid for one week, these authors found statistically significant differences in hardness for some of the tested materials, but not for Dyract AP and Spectrum TPH. The difference between their findings and ours may in part be a result of their accepting air-conditioned specimens as control, i.e., their specimens were not immersed in water. They stated that the best control was specimens conditioned in air for a stipulated time period. However, these materials will not be exposed to a dry environment in the mouth ${ }^{29)}$. Moreover, it is reported that the presence of water is crucially important for the deterioration of the composites ${ }^{28,35,37)}$. Hence, surface hardness of these materials is significantly affected by both water sorption and contact time with the aqueous media ${ }^{39)}$. In addition, Yap et $a l .{ }^{3)}$ immersed their specimens in test solutions immediately after light polymerization, in contrast to the present study, in which the specimens were conditioned following a week of storage in bidistilled water.

It has been shown that a majority of leachable organic components elute from the composite resin materials within the first seven days after curing using distilled water as a solvent ${ }^{40)}$. With increased storage time, the filler surface and/or the fillermatrix bond will be affected by the storage solution $^{41)}$. It is also known that water and weak intraoral acids (citric and lactic acids) can damage the inorganic fillers ${ }^{42)}$, and phosphoric acid has the ability to etch glass particles ${ }^{43)}$. Silica leaches out of composite materials as a result of stress corrosion attacks upon the glass fillers ${ }^{44)}$, and loss of structural ions from the glass phase of polyacid-modified composites has been shown to occur by acidic attack $^{31)}$. Degradation of the inorganic filler may play a role in reducing hardness ${ }^{3)}$. The leakage of filler constituents has been shown to produce cracks at the resin-filler interface ${ }^{44,45)}$, which may result in weakening of the material ${ }^{3,46)}$. Yap et $a l^{3)}$ reported that the greatest increase in surface roughness was noted when Dyract was conditioned in citric acid. Under SEM evaluation, a generalized roughening with the presence of numerous pits - was observed. This could have been caused by the loss of glass filler particles resulting from the disintegration of the coupling agent at the resin-filler interface. Therefore, the authors suggested that large-scale degradation of the resin-filler interface could possibly affect surface hardness.

Hardness loss of a material may contribute to a material's deterioration in a clinical environment, including loss of anatomical form and discoloration ${ }^{7)}$. Furthermore, chemical softening may have a negative effect on wear and abrasion rates ${ }^{3,7)}$, and consequently, the life span of a restorative material. Therefore, the results of the present study lend support to our previous finding $\mathrm{s}^{47)}$, which suggest that a patient's habit of dietary acids consumption may affect the durability of restorative materials in the oral environment.

\section{CONCLUSION}

Under the conditions of the present study, the observed differences in the surface microhardness of various tooth-colored restorative materials conditioned in several media varied according to three factors: $\mathrm{pH}$ of the acidic solution, nature of the acidic 
solution, and composition of the evaluated material.

\section{REFERENCES}

1) Wu W, Toth EE, Moffa JF, Ellison JA. Subsurface damage layer of in vivo worn dental composite restorations. J Dent Res 1984; 63: 675-680.

2) McKinney JE, Wu W. Chemical softening and wear of dental composites. J Dent Res 1985; 64: 1326-1331.

3) Yap AUJ, Low JS, Ong LFKL. Effect of foodsimulating liquids on surface characteristics of composite and polyacid-modified composite restoratives. Oper Dent 2000; 25: 170-176.

4) Jung CB, Kım HI, Kım KH, Kwon YH. Influence of $30 \%$ hydrogen peroxide bleaching on compomers in their surface modifications and thermal expansion. Dent Mater J 2002; 21: 396-403.

5) Stockton LW, Williams PT, Attallah C. The effect of prolonged packing on the surface hardness of posterior composites. Oper Dent 2002; 27: 266-270.

6) Wakamatsu Y, Kakuta K, Ogura H. Wear test combining simulated occlusal wear and toothbrush wear. Dent Mater J 2003; 22: 383-396.

7) Garcia-Godoy F, Garcia-Godoy A, Garcia-Godoy F. Effect of APF minute-foam on the surface roughness, hardness, and micromorphology of high-viscosity glass ionomers. J Dent Child 2003; 70: 19-23.

8) Okada K, Tosaki S, Hirota K, Hume WR. Surface hardness change of restorative filling materials stored in saliva. Dent Mater 2001; 17: 34-39.

9) Roulet JF. A materials scientist's view: Assessment of wear and marginal integrity. Quintessence Int 1987; 18: 543-552.

10) Suese K, Kawazoe T. Wear resistance of hybrid composite resin for crown material by the two-body sliding test. Dent Mater J 2002; 21: 225-237.

11) Geurtsen W, Leyhausen G, Garcia-Godoy F. Effect of storage media on the fluoride release and surface microhardness of four polyacid-modified composite resins ("compomers"). Dent Mater 1999; 15: 196-201.

12) Lingström $P$, Imfeld $T$, Birkhed D. Comparison of three different methods for measurements of plaque $\mathrm{pH}$ in humans after consumption of soft bread and potato chips. J Dent Res 1993; 72: 865-870.

13) El-Badrawy WA, McComb D. Effect of home-use fluoride gels on resin-modified glass-ionomer cements. Oper Dent 1998; 23: 2-9.

14) Garcia-Godoy F, Leon de Perez S. Effect of fluoridated gels on a light-cured glass ionomer cement: an SEM study. J Clin Pediatr Dent 1993; 17: 83-87.

15) Abu-bakr N, Han L, Okamoto A, Iwaku M. Changes in the mechanical properties and surface texture of compomer immersed in various media. J Prosthet Dent 2000; 84: 444-452.

16) Hughes JA, West NX, Parker DM, van den Braak $\mathrm{MH}$, Addy M. Effects of $\mathrm{pH}$ and concentration of citric, malic and lactic acids on enamel, in vitro. J Dent 2000; 28: 147-152.

17) Nicholson JW, Gjorgievska E, Bajraktarova B, Mckenzie MA. Changes in properties of polyacid- modified composite resins (compomers) following storage in acidic solutions. $J$ Oral Rehabil 2003; 30: 601607.

18) McLean JW, Nicholson JW, Wilson AD. Proposed nomenclature for glass-ionomer dental cements and related materials. Quintessence Int 1994; 25: 587-590.

19) Nicholson JW, Czarnecka B, Limanowska-Shaw H. A preliminary study of the effect of glass-ionomer and related dental cements on the $\mathrm{pH}$ of lactic acid storage solutions. Biomaterials 1999; 20: 155-158.

20) Karantakis $P$, Helvatjoglou-Antoniades $M$, Theodoridou-Pahini S, Papadogiannis Y. Fluoride release from three glass ionomers, a compomer, and a composite resin, in water, artificial saliva, and lactic acid. Oper Dent 2000; 25: 20-25.

21) Forss $H$. Release of fluoride and other elements from light-cured glass ionomers in neutral and acidic conditions. J Dent Res 1993; 72: 1257-1262.

22) Matsuya S, Matsuya $Y$, Yamamoto $Y$, Yamane $M$. Erosion process of a glass ionomer cement in organic acids solutions. Dent Mater J 1984; 3: 210-219.

23) Fukazawa M, Matsuya S, and Yamane $M$, The mechanism for erosion of glass-ionomer cements in an acidic buffer solution, J. Dent. Res., 1987, 66:1770-1774.

24) Fukazawa M, Matsuya S, Yamane M. The mechanism for erosion of glass-ionomer cements in organic-acid buffer solutions. J Dent Res 1990; 69: 1175-1179.

25) De Moor RJG, Verbeeck RMH. Effect of acetic acid on the fluoride release profiles of restorative glass ionomer cements Dent Mater 1998; 14: 261-268.

26) Nicholson JW, Czarnecka B, Limanowska-Shaw H. The long-term interaction of dental cements with lactic acid solutions. J Mater Sci Mater Med 1999; 10: 449.

27) El-Badrawy WA, McComb D, Wood RE. Effect of home-use fluoride gels on glass ionomer and composite restorations. Dent Mater 1993; 9: 63-67.

28) Attin T, Vataschki M, Hellwig E. Properties of resinmodified glass-ionomer restorative materials and two polyacid-modified resin composite materials. Quintessence Int 1996; 27: 203-209.

29) Cattani-Lorente MA, Dupuis V, Moya F, Payan J, Meyer JM. Comparative study of the physical properties of a polyacid-modified composite resin and a resinmodified glass ionomer cement. Dent Mater 1999; 15: 21-32.

30) Hickel RA, Folwaczny M. Various forms of glass ionomers and compomers. Oper Dent 2001; 6: 177-190.

31) Watts DC, Bertenshaw BW, Jugdev JS. pH and time dependence of surface degradation in a compomer biomaterial. J Dent Res 1995; 74: 912.

32) Attin T, Buchalla W, Trett A, Hellwig E. Toothbrushing abrasion of polyacid-modified composites in neutral and acidic buffer solutions. J Prosthet Dent 1988; 80: 148-150.

33) Wu W, Mc Kinney JE. Influence of chemicals on wear of dental composites J Dent Res 1982; 61: 1180-1183.

34) Chadwick RG, McCabe JF, Walls AWG, Storer R. The effect of storage media upon the surface microhardness and abrasion resistance of three composites Dent Mater 1990; 6: 123-128. 
35) Örtengren U, Andersson F, Elgh U, Terselius B, Karlsson S. Influence of $\mathrm{pH}$ and storage time on the sorption and solubility behavior of three composite resin materials J Dent 2001; 29: 35-41.

36) Nicholson JW, Millar BJ, Czarnecka B, LimanowskaShaw H. Storage of polyacid-modified resin composite ('compomers') in lactic acid solution. Dent Mater 1999; 15: 413 .

37) Umemoto K, Kurata S. Basic study of a new denture base resin applying hydrophobic methacrylate monomer. Dent Mater J 1997; 16: 21-30.

38) Fujii K, Ban S, McCabe JF. Toothbrush abrasion of paint-on resins shade modification of crown and bridge resins. Dent Mater J 2003; 22: 244-250.

39) Hansen EK. After-polymerization of visible light activated resins: surface hardness vs. light source. Scand J Dent Res 1983; 91: 406-410.

40) Örtengren U, Wellendorf $H$, Karlsson S, Ruyter IE. Water sorption and solubility of dental composites and identification of monomers released in an aqueous environment. J Oral Rehabil 2001; 28: 1106-1115.
41) Söderholm KJ, Zigan M, Ragan M, Fischlschweiger W, Bergman M. Hydrolytic degradation of dental composites. J Dent Res 1984; 63: 1248-1254.

42) McKinney JE. Posterior composite resin dental restorative materials. (Peter Szulc Publishing Co, Netherlands, 1985) 331-347.

43) Kula K, Nelson S, Kula T, Thompson V. In vitro effect of APF gel on the surface of composites with different filler particles. J Prosthet Dent 1986; 56: 161-169.

44) Söderholm KJ. Leaking of fillers in dental composites. J Dent Res 1983; 62: 126-130.

45) Roulet JF, Walti C. Influence of oral fluid on composite resin and glass-ionomer cement. J Prosthet Dent 1984; 52: 182-189.

46) Yoshida Y, Shirai K, Shintani H, Okazaki M, Suzuki K, Van Meerbeek B. Effect of presilanization filler decontamination on aesthetics and degradation resistance of resin composites. Dent Mater J 2002; 21: 383-395.

47) Dorter C, Yıldız E, Gomec Y, Erdilek D. Abrasive effect of brushing on ormocers following acid conditioning. Dent Mater J 2003; 22: 475-481. 